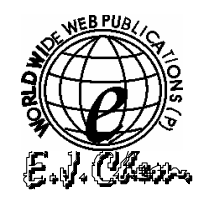

\title{
Facile and Sensitive Spectrophotometric Technique for the Determination of Carbofuran in its Formulations, Water and Grain Samples with Substituted Anilines
}

\author{
V. HARIKRISHNA and N.V.S.NAIDU* \\ Department of Chemistry, \\ Sri Venkateswara University, Tirupati-517 502, INDIA. \\ E-mail: nvsnaidu2@yahoo.co.in
}

Received 17 April 2005; Accepted 28 August 2005

\begin{abstract}
Methods are described for the determination of carbofuran in its formulations, in water and grain samples by the diazotization coupling spectrophotometric technique, using substituted anilines such as 4-bromoaniline, 4-methylaniline and 4-aminobenzaldehyde as the coupling agents. The orange red colour formed with 4-bromoaniline shows maximum absorption at $478 \mathrm{~nm}$, yellow colour obtained with 4-methylaniline have maximum absorption at $465 \mathrm{~nm}$ whereas a red colour derivative formed with 4-aminobenzaldehyde shows $\lambda_{\max }$ at $472 \mathrm{~nm}$. The methods could be successfully applied for the determination of carbofuran in its formulations, water and grain samples.
\end{abstract}

Key words: Carbofuran, substituted anilines, 4-bromoaniline, 4-methylaniline, 4-aminobenzaldehyde, spectrophotometry, water and grain samples

\section{Introduction}

Carbofuran (2,3 - dihydro-2,2-dimethyl-7-benzofuranyl methyl carbamate) is a systemic acaricide, insecticide and nematicide, applied to foliage to control insects and mites. Its formulations are commercially available under the trade names "Furadon", "Curraterr", and "Yaltox". It is found to be highly toxic to mammals ${ }^{1}$ and wild birds ${ }^{2-3}$. As a result of extensive usage there is a possibility of contamination of environment in water, soil, food etc., by this 
insecticide. Because of this importance several analytical procedures have been developed for the determination of carbofuran in its formulations and environmental samples, such as $\mathrm{GC}^{4-7}$, GLC $^{8-9}$, HPLC $^{10-13}$ and Spectrophotometric ${ }^{14-23}$ methods for determination of carbofuran. The reported methods has several disadvantages like poor sensitivity, selectivity, less stability of colour derivatives and few are required solvents for the extraction of colour derivative. We report here three facile, simple and sensitive spectrophotometric methods for the analysis of carbofuran. Diazotized 4bromoaniline, 4-methylaniline and 4-aminobenzaldehyde are being first time applied for the determination of carbofuran.

\section{Experimental}

\section{Apparatus}

An Elico - SL 159 UV VIS Spectrophotometer with $10 \mathrm{~mm}$ path length glass cells were used.

An Elico CL-110 digital pH meter, with combined glass electrode, was employed for $\mathrm{pH}$ measurement.

\section{Reagents}

a. Carbofuran - Analytical and Technical grade sample (99.4\%) supplied by Rallis India Ltd., Bangalore.

b. Standard Carbofuran solution $-50 \mu \mathrm{g} / \mathrm{ml}$ each in methanol.

c. Sodium nitrite, $0.5 \%(\mathrm{w} / \mathrm{v})$ aqueous

d. Sodium hydroxide, $2 \%(\mathrm{w} / \mathrm{v})$ aqueous

e. 4-bromoaniline, 4-methylaniline and 4-aminobenzaldehyde, $0.2 \%$ solutions were prepared by dissolving $0.2 \mathrm{~g}$ each of these reagents first in methanol and diluted to $100 \mathrm{ml}$ with distilled water.

\section{Procedure}

Aliquots of standard carbofuran $(0,0.5,1.0$, $6.0 \mathrm{ml})$ pesticide solution were taken into a series of $25 \mathrm{ml}$ standard flasks. To each one of these $2.5 \mathrm{ml}$ of $2 \% \mathrm{NaOH}, 2.4 \mathrm{ml}$ of $\mathrm{NaNO}_{2}$ and $2.0 \mathrm{ml}$ of 4-bromoaniline was added. The solutions were made upto the mark with distilled water. The resulting orange red coloured derivative had a maximum absorption at $478 \mathrm{~nm}$ against a reagent blank and remain stable for more than $48 \mathrm{~h}$. Absorbance values were recorded spectrophotometrically. The plot between concentration $v s$ absorbance was linear over the composition studied. Similarly 4-methylaniline and 4-aminobenzaldehyde were used for the color development as described above.

\section{Recovery of carbofuran from spiked grains}

$100 \mathrm{~g}$ of each grain (rice and wheat) were spiked with $200 \mathrm{ml}$ chloroform for $5 \mathrm{~min}$. The samples were fortified with different concentrations of insecticide in methanol and blended for $3 \mathrm{~min}$. Chloroform was filtered into $250 \mathrm{ml}$ standard flask through Whatman No.1 filter paper and the residue was retained. The residue was washed twice with $10 \mathrm{ml}$ chloroform and blended for $2 \mathrm{~min}$. Chloroform extracts were combined and made up to the mark. Known aliquots of the chloroform extracts were used for colour development after evaporating chloroform on a steam bath. The residue was dissolved in methanol and the amount was determined spectrophotometrically.

\section{Determination of recovery in fortified water samples}

After collection of the water samples, (minimum volume one litre) the $p H$ values were adjusted below 4 with $20 \%$ sulphuric acid. Then fortified with different concentrations of insecticide dissolved in methanol. Next extract each sample in a $250 \mathrm{ml}$ separating funnel with $100 \mathrm{ml}$ of chloroform. The chloroform extract were transferred into a funnel and re-extracted the aqueous phase twice with further $50 \mathrm{ml}$ of chloroform. The second chloroform extract was added to the first and washed the combined extract with $0.1 \mathrm{M}$ potassium carbonate solution, then dried the chloroform by passing it through anhydrous sodium sulphate in a filter funnel and collected the extract in a $250 \mathrm{ml}$ flask. The chloroform extract was reduced to $100 \mathrm{ml}$. 


\section{Results and Discussion}

The optical characteristics, accuracy and precision data of the carbofuran with substituted anilines namely 4-bromoaniline, 4-methylaniline and 4-aminobenzaldehyde were shown in Table 1. The method was based on the alkaline $(\mathrm{NaOH})$ hydrolysis of carbofuran to form carbofuran phenol. The carbofuran phenol was coupled with diazotized salts of 4-bromoaniline, 4-methylaniline and 4aminobenzaldehyde to produce coloured derivatives. The colour derivatives are formed instantaneously and stable for longer period than the earlier methods. The Calibration curves for all the aromatic substituted amines followed Beer's law, which obeyed over the concentration range 0.5 to $16 \mu \mathrm{g} / \mathrm{ml}$ for 4-bromoaniline, $0.4-14 \mathrm{~g} / \mathrm{ml}$ for 4-methylaniline and $0.2-10 \mu \mathrm{g} / \mathrm{ml}$ for 4 aminobenzaldehyde. The methods are free from the interference of the other pesticides.

Table 1. Optical characteristics, precision and accuracy of the method using diazotized reagents.

\begin{tabular}{|c|c|c|c|}
\hline Optical parameters & 4-Bromoaniline & 4-Methylaniline & 4-Aminobenzaldehyde \\
\hline $\begin{array}{c}\text { Concentration range } \\
\left(\mu \mathrm{g} \mathrm{ml}^{-1}\right)\end{array}$ & $0.5-16.0$ & $0.4-14.0$ & $0.2-10.0$ \\
\hline Color of the complex & Orange red & Yellow & Red \\
\hline Stability (h) & 48 & 36 & 30 \\
\hline$\lambda_{\max }(\mathrm{nm})$ & 478 & 465 & 471 \\
\hline $\begin{array}{l}\text { Limit of detection } \\
\qquad\left(\mu \mathrm{g} \mathrm{ml}^{-1}\right)\end{array}$ & 0.645 & 0.564 & 0.355 \\
\hline $\begin{array}{l}\text { Limitof quantification } \\
\qquad\left(\mu \mathrm{g} \mathrm{ml}^{-1}\right)\end{array}$ & 3.065 & 2.678 & 1.355 \\
\hline $\begin{array}{l}\text { Molar absorptivity } \\
\quad\left(1 \mathrm{~mol}^{-1} \mathrm{~cm}^{-1}\right)\end{array}$ & $5.361 \div 10^{4}$ & $3.765 \div 10^{4}$ & $6.698 \div 10^{4}$ \\
\hline $\begin{array}{l}\text { Sandell's sensitivity } \\
\qquad\left(\mu \mathrm{g} \mathrm{cm}^{-2}\right)\end{array}$ & 0.0132 & 0.0114 & 0.0105 \\
\hline $\begin{array}{l}\text { Regression equation } \\
\text { Slope (a) }\end{array}$ & 0.1874 & 0.4675 & 0.3254 \\
\hline Intercept (b) & 0.0156 & 0.2541 & 0.0126 \\
\hline $\begin{array}{l}\text { Correlation coefficient } \\
\qquad(\mathrm{r})\end{array}$ & 0.9998 & 0.9879 & 0.9997 \\
\hline $\begin{array}{l}\text { Relative standard } \\
\text { deviation }^{\mathrm{b}}\end{array}$ & 1.234 & 0.8421 & 1.3561 \\
\hline Relative error & 0.98 & 1.02 & 0.87 \\
\hline
\end{tabular}

The recovery percentage of carbofuran in its formulations ranges between 98 to $99.2 \%$ using diazotized reagents and shown in Table $2-4$. Table $5-7$ indicates the percentage recovery of carbofuran from fortified water (distilled and tap) samples in the range of 95 to $99.3 \%$ Percentage recovery of carbofuran from vegetable samples (potato and tomato) ranges between 96.1 to $99.3 \%$. It is evident from above tables that the proposed methods are very simple, facile, sensitive, rapid and inexpensive than the reported methods in the literature. The performance of the present methods can be successfully compared with the reported methods. ${ }^{18}$ 
Table 2. Determination of carbofuran in insecticidal formulations using 4-bromoaniline as a coupling agent.

\begin{tabular}{ccccc}
\hline Sample No. & $\begin{array}{c}3 \% \\
\text { Granules }\end{array}$ & $\begin{array}{c}10 \% \\
\text { Formulations }\end{array}$ & $\begin{array}{c}50 \% \text { Soluble } \\
\text { powder }\end{array}$ & $\begin{array}{c}75 \% \text { Wettable } \\
\text { powder }\end{array}$ \\
\hline 1 & 2.91 & 9.95 & 49.89 & 74.89 \\
2 & 2.95 & 9.94 & 49.85 & 74.95 \\
3 & 2.91 & 9.96 & 49.75 & 74.89 \\
4 & 2.95 & 9.97 & 49.75 & 74.96 \\
5 & 2.89 & 9.96 & 49.89 & 74.87 \\
6 & 2.98 & 9.93 & 49.95 & 74.50 \\
7 & 2.91 & 9.90 & 49.68 & 74.85 \\
8 & 2.94 & 9.94 & 49.50 & 74.75 \\
Mean & 2.93 & 9.94 & 48.84 & 73.67 \\
SD & 0.065 & 0.089 & 0.251 & 0.552 \\
\hline
\end{tabular}

Table 3. Determination of carbofuran in insecticidal formulations using 4-methylaniline as a coupling agent.

\begin{tabular}{ccccc}
\hline & $\begin{array}{c}3 \% \\
\text { Granules }\end{array}$ & $\begin{array}{c}10 \% \\
\text { Formulations }\end{array}$ & $\begin{array}{c}50 \% \text { Soluble } \\
\text { powder }\end{array}$ & $\begin{array}{c}\text { 75\% Wettable } \\
\text { powder }\end{array}$ \\
\hline 1 & 2.95 & 9.93 & 49.95 & 74.94 \\
2 & 2.94 & 9.96 & 49.90 & 74.94 \\
3 & 2.93 & 9.94 & 49.85 & 74.93 \\
4 & 2.95 & 9.93 & 49.79 & 74.95 \\
5 & 2.82 & 9.92 & 49.91 & 74.82 \\
6 & 2.95 & 9.97 & 49.93 & 74.78 \\
7 & 2.93 & 9.95 & 49.85 & 74.90 \\
8 & 2.97 & 9.96 & 49.65 & 74.92 \\
Mean & 2.93 & 9.94 & 49.85 & 74.89 \\
SD & 0.043 & 0.016 & 0.090 & 0.058 \\
\hline
\end{tabular}

Table 4. Determination of carbofuran in insecticidal formulations using 4-aminobenzaldehyde.

\begin{tabular}{ccccc}
\hline Sample No. & $\begin{array}{c}3 \% \\
\text { Granules }\end{array}$ & $\begin{array}{c}10 \% \\
\text { Formulations }\end{array}$ & $\begin{array}{c}50 \% \text { Soluble } \\
\text { powder }\end{array}$ & $\begin{array}{c}75 \% \text { Wettable } \\
\text { powder }\end{array}$ \\
\hline 1 & 2.95 & 9.97 & 49.90 & 74.90 \\
2 & 2.97 & 9.92 & 49.89 & 74.85 \\
3 & 2.93 & 9.93 & 49.78 & 74.94 \\
4 & 2.95 & 9.95 & 49.90 & 74.93 \\
5 & 2.94 & 9.94 & 49.95 & 74.90 \\
6 & 2.92 & 9.93 & 49.92 & 74.75 \\
7 & 2.90 & 9.93 & 49.75 & 74.85 \\
8 & 2.93 & 9.95 & 49.65 & 74.85 \\
Mean & 2.9362 & 9.94 & 49.84 & 74.87 \\
SD & 0.019 & 0.046 & 0.097 & 0.056 \\
\hline
\end{tabular}


Table 5. Recovery of carbofuran from fortified water sample using diazotized 4-bromoaniline as a coupling agent.

\begin{tabular}{cccccc}
\hline \multirow{2}{*}{ S.No. } & Fortification & \multicolumn{2}{c}{ Distilled water } & \multicolumn{2}{c}{ Tap water } \\
\cline { 3 - 5 } & level $\left(\mu \mathrm{g} \mathrm{ml}^{-1}\right)$ & $\begin{array}{c}\text { Amount of } \\
\text { recovery } \\
\left(\mu \mathrm{g} \mathrm{ml}^{-1}\right)\end{array}$ & $\begin{array}{c}\text { Recovery } \\
\text { percentage }\end{array}$ & $\begin{array}{c}\text { Amount of } \\
\text { recovery } \\
\left(\mu \mathrm{g} \mathrm{m}^{-1}\right)\end{array}$ & $\begin{array}{c}\text { Recovery } \\
\text { percentage }\end{array}$ \\
\hline 1 & 0.5 & 0.49 & 98.0 & 0.48 & 96.0 \\
2 & 1.0 & 0.99 & 99.0 & 0.98 & 98.0 \\
3 & 1.5 & 1.48 & 98.6 & 1.45 & 96.6 \\
4 & 2.0 & 1.97 & 98.5 & 1.95 & 97.5 \\
5 & 2.5 & 2.48 & 99.2 & 2.45 & 98.0 \\
6 & 3.0 & 2.94 & 98.0 & 2.91 & 97.0 \\
\hline
\end{tabular}

Table 6. Recovery of carbofuran from fortified water sample using diazotized 4-methylaniline as a coupling agent.

\begin{tabular}{|c|c|c|c|c|c|}
\hline \multirow[b]{2}{*}{ S.No. } & \multirow[b]{2}{*}{$\begin{array}{l}\text { Fortification } \\
\text { level }\left(\mu \mathrm{g} \mathrm{ml}^{-1}\right)\end{array}$} & \multicolumn{2}{|c|}{ Distilled water } & \multicolumn{2}{|c|}{ Tap water } \\
\hline & & $\begin{array}{c}\text { Amount of } \\
\text { recovery }\left(\mu \mathrm{g} \mathrm{ml}^{-1}\right)\end{array}$ & $\begin{array}{l}\text { Recovery } \\
\text { percentage }\end{array}$ & $\begin{array}{l}\text { Amount of } \\
\text { recovery } \\
\left(\mu \mathrm{g} \mathrm{ml}^{-1}\right)\end{array}$ & $\begin{array}{l}\text { Recovery } \\
\text { percentage }\end{array}$ \\
\hline 1 & 0.4 & 0.39 & 97.5 & 0.38 & 95.0 \\
\hline 2 & 0.8 & 0.78 & 97.5 & 0.78 & 97.5 \\
\hline 3 & 1.2 & 1.18 & 98.3 & 1.17 & 97.5 \\
\hline 4 & 1.6 & 1.58 & 98.7 & 1.57 & 98.1 \\
\hline 5 & 2.0 & 1.96 & 98.0 & 1.95 & 97.5 \\
\hline 6 & 2.4 & 2.37 & 98.7 & 2.36 & 98.3 \\
\hline
\end{tabular}

Table 7. Recovery of carbofuran from fortified water sample using diazotized 4-aminobenzaldehyde as a coupling agent.

\begin{tabular}{cccccc}
\hline & & \multicolumn{2}{c}{ Distilled water } & \multicolumn{2}{c}{ Tap water } \\
\cline { 3 - 5 } S.No. & $\begin{array}{c}\text { Fortification } \\
\text { level }\left(\mu \mathrm{g} \mathrm{ml}^{-1}\right)\end{array}$ & $\begin{array}{c}\text { Amount of } \\
\text { recovery }\left(\mu \mathrm{g} \mathrm{ml}^{-1}\right)\end{array}$ & $\begin{array}{c}\text { Recovery } \\
\text { percentage }\end{array}$ & $\begin{array}{c}\text { Amount of } \\
\text { recovery } \\
\left(\mu \mathrm{g} \mathrm{ml}^{-1}\right)\end{array}$ & $\begin{array}{c}\text { Recovery } \\
\text { percentage }\end{array}$ \\
\hline 1 & 0.2 & 0.19 & 95.0 & 0.19 & 95.0 \\
2 & 0.8 & 0.79 & 98.7 & 0.77 & 97.4 \\
3 & 1.4 & 1.38 & 98.5 & 1.36 & 97.1 \\
4 & 2.0 & 1.97 & 98.5 & 1.96 & 98.0 \\
5 & 2.6 & 2.58 & 99.2 & 2.57 & 98.8 \\
6 & 3.2 & 3.18 & 99.3 & 3.17 & 99.0 \\
\hline
\end{tabular}

Hence, the proposed methods can be adopted for the routine analysis of the purity of the commercial formulations and environmental samples.

\section{Acknowledgement}

The authors are thankful to Rallis India Limited., Bangalore, for supplying the analytical and technical grade sample of carbofuran.

\section{References}

1. Tolein J S, J. Occup. Med, 1970, 12, 16.

2. Hill E F and Camardese, M D, Ecotoxicol. Environ. Saf., 1984, 8, 551.

3. Balcomb R and Bowen C A, J. Wildl. Manage, 1984, 48, 1353.

4. Van Middelem C H, Moye, H A and Janes M J, J. Agric. Food Chem., 1971, 19, 459.

5. Williams I H and Brown M J, J. Agric. Food. Chem., 1973, 21, 399. 
6. Bruce C L, James C M, Robert C H and Glenn H F, J. Agric. Food Chem., 1983, 31,220.

7. Butler L I and McDonagh L M, J. Agric Food. Chem., 1968, 16, 403.

8. $\quad$ Cassil C C, Stanovick R P and Cassil C C, Res. Rev., 1969, 26, 63.

9. $\quad$ Seiber J N, J. Agric Food. Chem., 1972, 20, 443.

10. Nelsen T R and Cook R F, J. Agric. Food. Chem., 1980, 28, 719.

11. Frei R w, Lawrence J F, Hope J and Cassidy R M, J. Chromatogr. Sci., 1974, 12, 40.

12. Cramer P H, Drinkwine A D,Golng J E and Carey A E, J. Chromatogr., 1982, 235, 489.

13. Goewie C E and Hogendoorn E A, J. Chromatogr., 1987, 404, 351.

14. Rajeswari C V and Naidu P R, J. Food Sci. Technol., 1986, 23, 101.

15. Rangaswamy J R, Vijayashankar Y N and Prakash S R, J. Assoc. off. Anal. Chem., 1976, 591276.

16. Handa S K and Dikshit A K, J. Assoc. Off. Anal. Chem., 1978, 66,1513.

17. Handa S K, J. Assoc. Off. Anal. Chem., 1980, 63 (2), 200.

18. Appaiah K M, Ramakrishna R, Subba Rao K R, Nagaraja K V and Kapur O P, J. Food Sci. Technol., 1982, 19, 211.

19. Zanella R, Dallago R M, Flores E M M and Martins A F, Analytical Letters., 1999, 32 (3), $593-600$.

20. Kesari R, Das J V and Gupta V K, Journal of the Indian Chemical Society, 1998,75,181.

21. Alvavezrodriguez L, Monferrer pons L, Esteveromero J S, Garciaalvarez coque M C and Ramisramos G, Analyst, 1997, 122 (5), 459-463.

22. Agrawal O and Gupta, V K, Microchemical Journal., 1999, 62 (1), 147-153.

23. Nunes G S, Ribeiro M L, Polese L and Banalo D, J. Chromatogr. A., 1998, 795 (1), 43-51.

24. Abad A, Moreno M J, Pelegri R, Martina M I, Saez A, Gamon M, and Montoya A, J. Chromatogr. A., 1999, 833 (1), 3-12.

25. Mithyantha M S and Perur N G, Current Science, 1974, 43, 578.

26. Vanisha Das J, Ramachandran K N and Gupta U K, J. Anal. Chem., 1994, 348, 840.

27. Naidu D V and Naidu P R, Proc. Indian Natl. Sci. Acad., 1990, 56, 203.

28. Santos Delgado M J, Rubio Barroso S, Toledano Fernandez-Tastado G, and Polo-Diez L M, J. of Chromatography, A. 2001, 921, 287. 


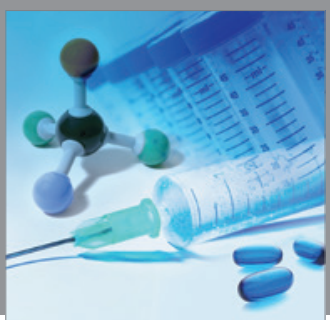

International Journal of

Medicinal Chemistry

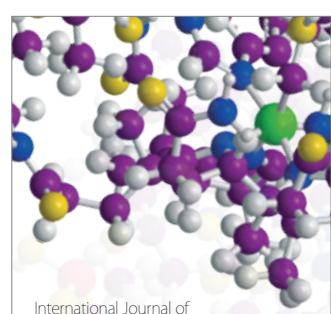

Carbohydrate Chemistry

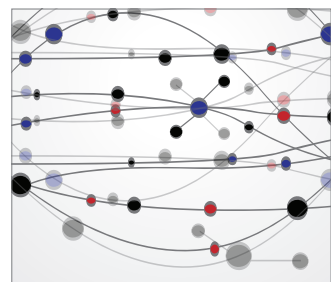

The Scientific World Journal
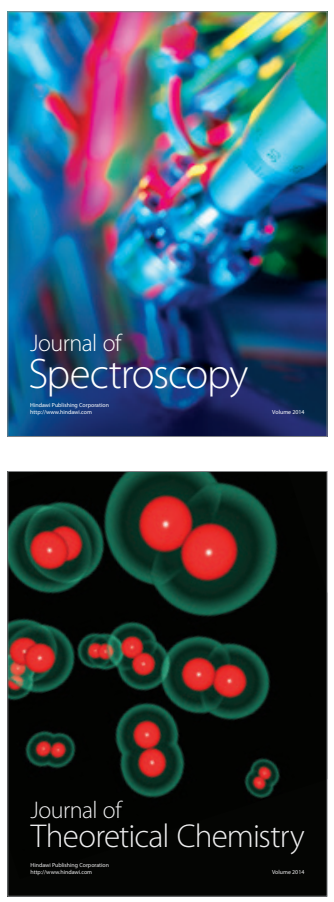
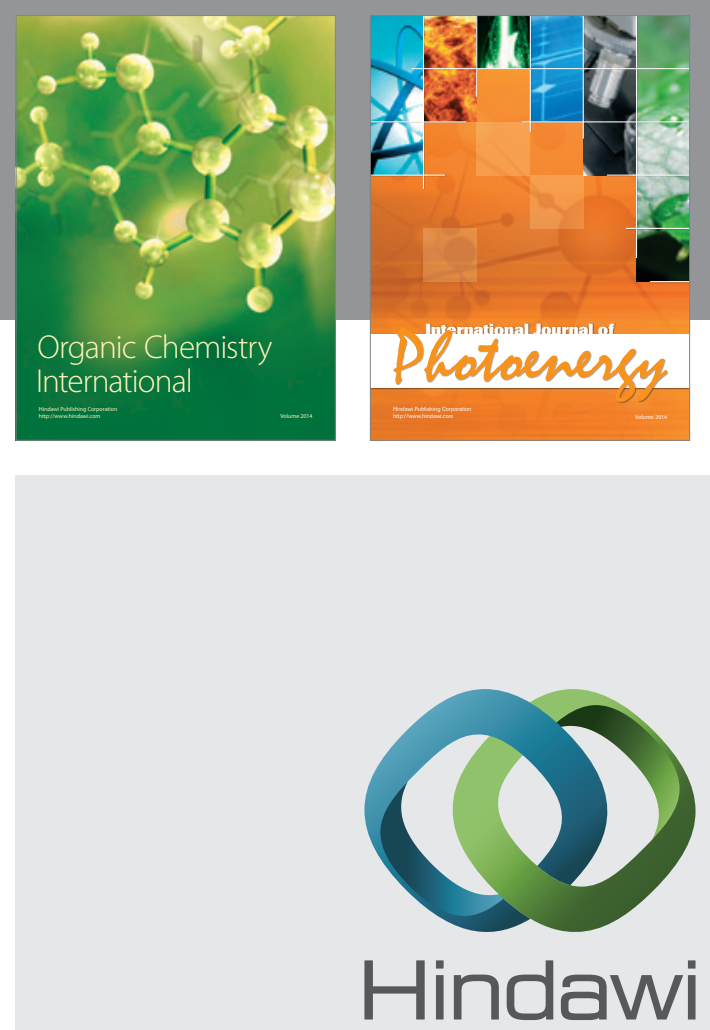

Submit your manuscripts at

http://www.hindawi.com
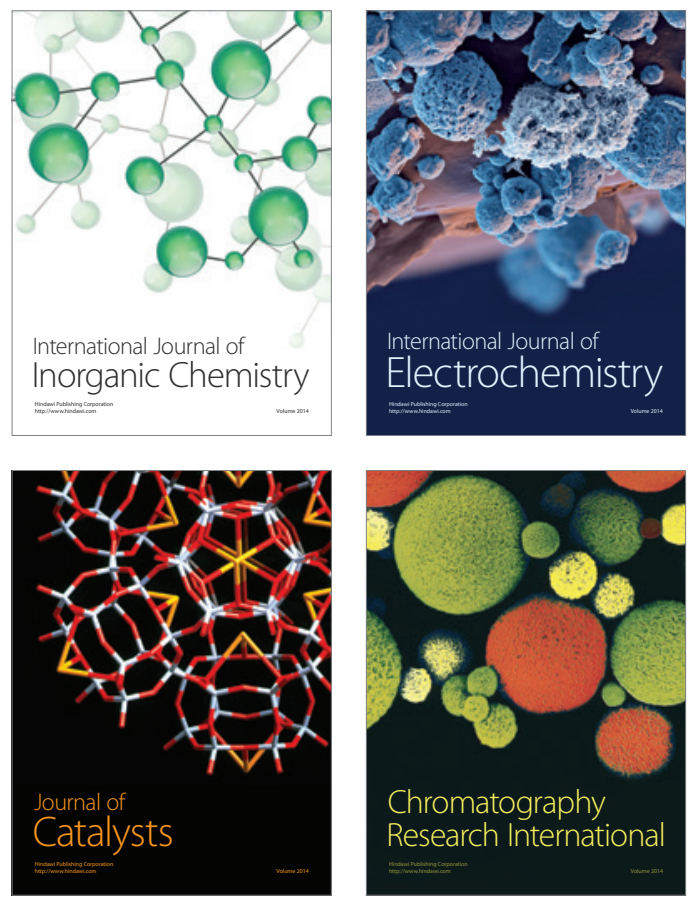
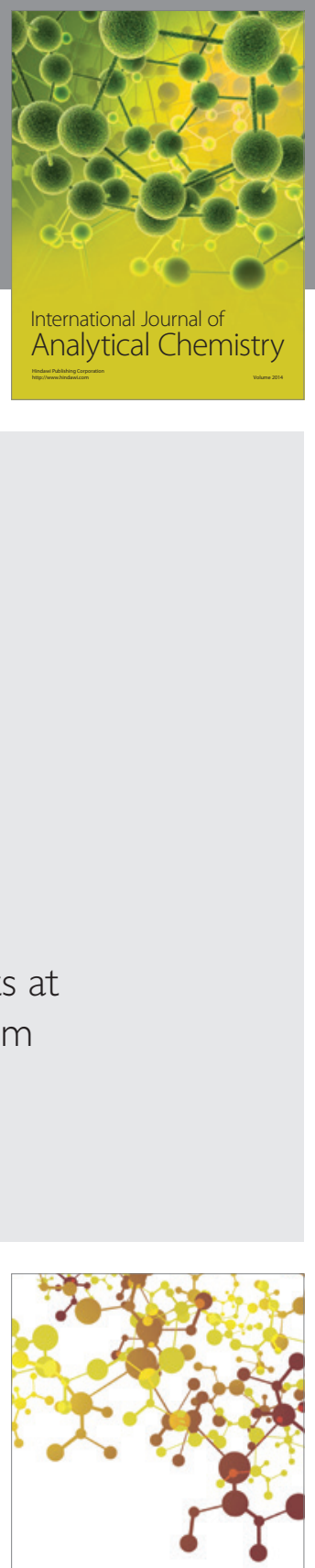

Journal of

Applied Chemistry
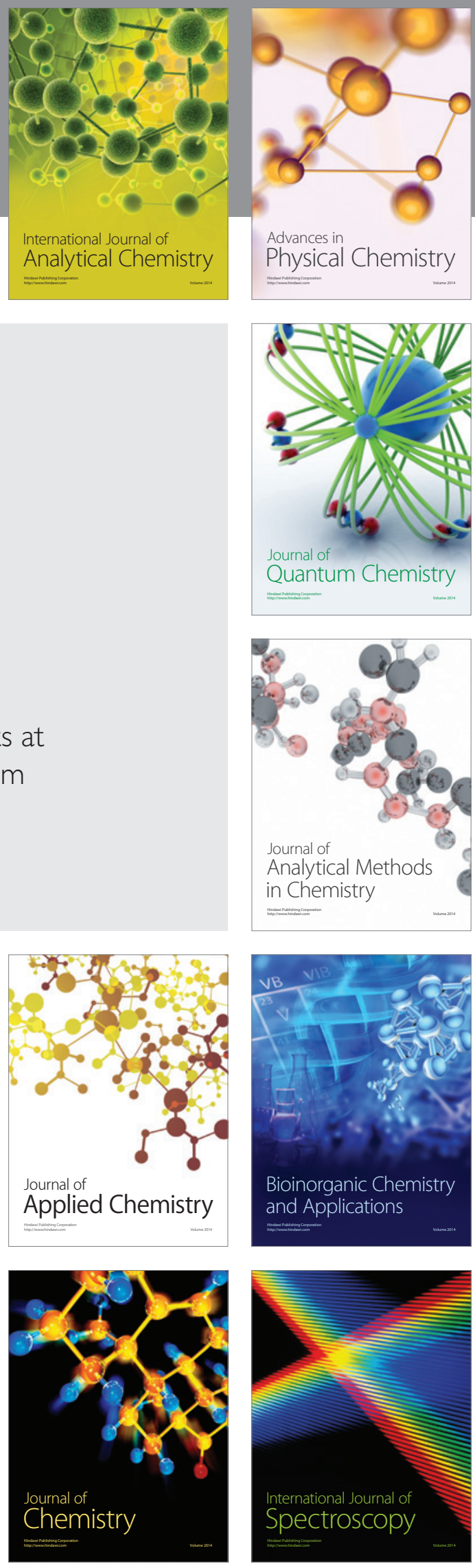